\title{
KOMUNIKASI DAN RESOLUSI KONFLIK SOSIAL
}

\section{Pendahuluan}

Dalam kehidupan bermasyarakat, manusia selalu dihadapkan pada dua modus eksistensi. Menurut Fromm, ada dua modus eksistensi manusia, modus pertama adalah kecenderungan untuk "memiliki" (to have) dan modus keduanya adalah kecenderungan untuk "ingin menjadi" (to be). ${ }^{1}$ Modus pertama mengarah kepada keinginan yang kuat untuk memiliki "to have" sesuatu dalam bentuk material dengan simbol-simbol statusnya, seperti merasa sebagai kelompok eksklusif yang terhormat. Sangat menarik dicermati karena obsesi kepemilikan ini justru lebih kuat pada status dan kekuasaan. Karena itu, nafsu memiliki ini menjadi tidak sehat dan bahkan menimbulkan letupan-letupan konflik di masyarakat.

Modus kedua dari eksistensi manusia ini adalah ingin menjadi "to be", seseorang yang berkepribadian, mengaktualisasikan diri melalui ikhtiar dan kerja keras, sehingga terpenuhinya identitas diri berlangsung melalui proses. Tentu saja dorongan semacam ini erat kaitannya dengan kesadaran manusia akan kodratnya, akan potensinya yang tidak saja sekedar menerima dan menimbun kepemilikan, tetapi ada orientasi yang berlandaskan perilaku produktif yang konstruktif, memberi, dan tidak lepas dari restu masyarakat. Saat to have (kecenderungan untuk memiliki) lebih dominan daripada to be (kecenderungan untuk ingin menjadi) maka akan melahirkan konflik.

Dalam wacana konteks dan konstelasi sosial yang lebih sempit, suatu masalah dalam komunikasi pembangunan seringkali tidak dapat diselesaikan dengan satu kebijakan dari atas/pemerintah saja. Tapi diperlukan berbagai kebijakan secara simultan (agar sinergis) sehingga dengan demikian diperlukan suatu perlu koordinasi yang matang. Masalah koordinasi yang bila dilaksanakan tidak tepat inilah yang akan menyebabkan terjadinya suatu overlapping kebijakan yang tidak efektif (tidak tepat sasaran) dan efisien (sekedar menghabiskan anggaran). Disamping itu, tumpang tindih ini dapat menyebabkan suatu konflik kepentingan di antara yang mengeluarkan suatu kebijakan. Disisi lain, potensi konflik yang laten akan menjadi konflik terbuka di antara stakeholders.

Sebelum terjadinya suatu konflik terbuka yang disebabkan oleh suatu kebijakan pemerintah, pemerintah khususnya yang berada di daerah sangat perlu mempertimbangkan

1 Fromm, Erich, To Have or To Be?, (New York: Continuum, 2008, originally published in 1976). 
eksistensi dan peran manajemen konflik dalam setiap program pembangunan (komunikasi pembangunan). Ketidak terlibatan aspek manajemen konflik dalam kebijakan komunikasi pembangunan (pembangunan) seringkali akan terlihat adanya tumpah tindih program maupun kebijakan yang tidak komprehensif untuk menyelesaikan permasalahan pembangunan itu sendiri. Berkaitan dengan suatu kebijakan khususnya komunikasi yang diambil pemerintah belum tentu dapat diterima semua kelompok masyarakat. Oleh karenanya, setiap komunikasi pembangunan harus memiliki argumentasi logis yang mendasari pengambilan keputusan tersebut. Pertimbangan keputusan komunikasi yang tidak logis dan tidak argumentatif akan memberi peluang interpretasi yang beragam. Dengan demikian bila semakin jauh alur komunikasi yang terjadi tersebut akan semakin bias hasil yang terjadi.

Dengan adanya otonomi daerah, alur kebijakan komunikasi (terutama yang berkaitan dengan konflik di daerah) menjadi sangat pendek. Pemerintah akan lebih mengetahuai tentang publik yang ada di wilayahnya. Pengetahuan yang pasti tentang "siapa publik" (Whom) komunikasi yang akan disampaikan adalah yang sangat penting dalam rangka mempertanggung jawabkan secara akuntabilitas, responsiveness, transparansi dari suatu kebijakan komunikasi, terutama ketika komunikasi dilihat dan dipandang sebagai proses penyelesaian konflik sosial yang ada.

\section{Kasus Tolikara: Paparan Awal sebagai Bukan Sekedar Konflik Agama tapi Konflik Sosial}

Konflik di Tolikara sangat menyedihkan dan patut dikecam sekeras-jerasnya. Pertama, umat Kristen dari Gidi (Gereja Injili di Indonesia) menyerang umat Islam yang sedang melaksanakan shalat Idul Fitri 1 Syawal 1436 H di Markas Korem 1702-11 di Tolikara. Kedua, aparat keamanan sama sekali tidak antisipatif. Sejatinya antisipatif, karena pimpinan Gidi sudah membuat surat yang melarang umat Islam melaksanakan shalat Idul Fitri dilapangan dan memasang pengeras suara. Selain itu, pada saat yang sama, umat Nasrani dari Gidi melaksanakan kebaktian rohani sekaligus seminar internasional dengan jarak sekitar 200 meter dari lapangan tempat diselenggarakannya shalat Idul Fitri, sehingga patut diduga bisa menciptakan konflik horizontal. Ketiga, aparat intelejen dapat dikatakan tidak bekerja, sehingga kebobolan dan terjadi konflik yang nyaris memporak-porandakan persatuan dan kesatuan bangsa Indonesia. Keempat, aparat keamanan sama sekali tidak berdaya menghadapi massa Gidi yang beringas, sehingga leluasa mengusir umat Islam yang sedang melaksanakan shalat Idul Fitri. 
Akibatnya mereka lari tunggang langgang menyelamatkan diri dari amukan massa Gidi. Kelima, ekstrimisme yang selama ini disandangkan kepada umat Islam, dan dalam banyak kasus menjadi sasaran penyerangan dari Densus 88 dalam memerangi terorisme, terbukti pada agama lain melakukan hal yang sama, tetapi treatmentnya berbeda.

Ini bisa menimbulkan perasaan tidak adil karena tidak equal dalam penanganannya. Permasalahan di Tolikara Tolikara sebagai bagian dari Papua dan bangsa Indonesia menyimpan banyak permasalahan. Saya menduga paling tidak ada 5 (lima) masalah besar yang dihadapi masyarakat Tolikara. Pertama, kurang pendidikan. Merujuk pernyataan Anies Baswedan, Menteri Pendidikan dan Kebudayaan RI pada saat buka puasa Kahmi di rumah dinasnya di Widya Chandra Jakarta Selatan beberapa hari menjelang Idul Fitri $1436 \mathrm{H}$ bahwa 76 persen pendidikan masyarakat Indonesia hanya tamat SMP ke bawah, dan hanya 6 persen yang berpendidikan sarjana, dapat ditarik kesimpulan bahwa pendidikan masyarakat Tolikara pasti tidak jauh berbeda seperti yang diungkapkan Menteri Anies Baswedan. Ini masalah besar karena mereka yang berpendidikan rendah bukan saja mudah disulut untuk konflik, tetapi hampir dipastikan mereka hidup miskin dan terkebelakang. Kedua, kesenjangan sosial ekonomi. Konsekuensi logis dari kurang pendidikan, maka masyarakat asli Tolikara tidak bisa bersaing dalam bidang ekonomi. Akibatnya pendatang yang pada umumnya Muslim lebih menguasai ekonomi, sehingga terjadi kesenjangan ekonomi yang kemudian menghadirkan kecemburuan sosial. Hal tersebut menjadi salah satu pemicu konflik horizontal di Tolikara. Ketiga, penjajahan ekonomi. Sudah menjadi rahasia umum bahwa di negeri yang kita cintai masih terjadi penjajahan ekonomi. Masyarakat Tolikara merasakan hal itu. Papua yang kekayaan alamnya luar biasa, tetapi masyarakatnya masih hidup miskin dan terkebelakang. Jika ada yang memicu, maka mereka segera melampiaskan kemarahan dengan melakukan konflik seperti konflik Tolikara. Keempat, ketidak-adilan dalam berbagai bidang. Masyarakat Tolikara merasakan banyaknya ketidakadilan dalam bidang ekonomi, sosial, hukum dan sebagainya, sehingga mudah disulut untuk melakukan konflik. Berbagai ketidakadilan merupakan hotspot yang setiap saat bisa melahirkan konflik horizontal dan vertikal. Kelima, separatisme. Permasalahan terbesar yang dihadapi di Tolikara dan Papua ialah adanya agenda memisahkan Papua dari Negara Kesatuan Republik Indonesia (NKRI). Masalah ini tidak kunjung selesai karena pihak asing turut bermain untuk mendorong Papua merdeka seperti Timor Timur. Dengan demikian, konflik Tolikara 
merupakan akumulasi dari berbagai persoalan yang dihadapi masyarakat yang selama ini terpendam akibat pendekatan represif.

Motif konflik kalau belajar dari konflik Aceh, dan konflik Papua, yang keduanya merupakan konflik vertikal. Begitu pula konflik Ambon, konflik Poso dan konflik lainnya di Indonesia, yang pada umumnya merupakan konflik horizontal

Konflik Tolikara dipicu tiga faktor. Pertama, motif ekonomi. Hampir semua konflik di Indonesia baik konflik vertikal maupun konflik horizontal, penyebab utamanya adalah faktor ekonomi. Oleh karena itu, saya berkeyakinan bahwa konflik Tolikara, pemicu utamanya adalah faktor sosial ekonomi. Dalam realitas sosial ekonomi, pendatang dimanapun selalu lebih maju tingkat kehidupan ekonomi mereka ketimbang penduduk asli. Kesenjangan sosial ekonomi tersebut, saya menduga keras menjadi pemicu konflik di Tolikara. Kedua, ketidakadilan dalam berbagai bidang. Di negeri kita masih banyak ketidakadilan. Rakyat jelata yang pada umumnya kurang pendidikan dan miskin, menjadi sasaran empuk dari praktik ketidakadilan. Masyarakat Tolikara juga merasakan ketidakadilan. Misalnya Papua luar biasanya kekayaan alamnya, tetapi masyarakatnya masih bodoh, miskin dan terkebelakang. Kondisi demikian mudah dieksploitasi untuk marah dan mengamuk. Salah satu bentuknya menyerang kaum Muslim yang sedang shalat Idul Fitri di Tolikara. Ketiga, separatisme. Sudah bukan rahasia umum bahwa oknum-oknum pemimpin agama di Papua bukan saja mendukung separatisme, tetapi berdasarkan pengalaman saya sewaktu menjadi anggota parlemen di awal Orde Reformasi, saya menduga mereka menjadi prime mover untuk mewujudkan separatisme di Papua. Upaya separatisme terus berkobar karena mendapat dukungan dari pihak asing yang ingin menguasai Papua yang kekayaan alamnya luar biasa dengan cara memerdekan Papua.

Oleh karena itu, konflik di Tolikara pemicu utamanya bukan faktor agama tetapi faktor separatisme, yang ingin memisahkan Papua dari negara kesatuan republik Indonesia dengan mengobarkan konflik agama sebagai strategi untuk menarik dukungan internasional jika umat Islam yang diserang di Tolikara mendapat simpati dan bantuan dari saudara-saudara mereka di daerah lain dan melakukan balas dendam terhadap umat Nasrani di Papua dan daerah lain di Indonesia.

Salah satu catatan media yang memperkuat pernyataan di atas adalah (diambil dari http://www.cnnindonesia.com/nasional/20150720145313-20-67278/insiden-tolikara-bukanhanya-konflik-agama/: 
Peristiwa pembakaran masjid Tolikara, Papua ketika Hari Raya Idul Fitri pada Jumat (17/7) bukan hanya disebabkan oleh konflik agama. Menurut Zainal Bagir, Ketua Program Studi Agama dan Lintas Budaya Universitas Gadjah Mada, ada beberapa faktor yang menyebabkan terjadinya peristiwa tersebut seperti politik lokal, kecemburuan sosial, dan keamanan.

Menurut Zainal, tren politik lokal yang ada di Indonesia bisa dengan mudah memicu konflik. Politik lokal menggunakan simbol agama untuk menciptakan konflik. Dirinya mengatakan konflik yang disebabkan oleh politik lokal terjadi di berbagai daerah tidak hanya terjadi di papua. Dirinya mencontohkan beberapa kasus seperti kasus penyerangan komunitas Syi'ah di Sampang, kasus Gerjea HKBP Filadelfia di Bekasi, dan kasus pembangunan Masjid Nur Musafir di Batulpat, Kupang.

"Politik lokal di Indonesia menyediakan arena untuk konflik misalnya memanipulasi simbol agama," kata Zainal, ketika dihubungi CNN Indonesia pada Senin (20/7).

Faktor lainnya, menurut Zainal, adanya pendatang yang mempunyai status ekonomi lebih baik memicu kecemburuan sosial bagi warga lokal. Dia juga menambahkan adanya UU Otonomi Khusus Papua menyebabkan ketegangan dan klaim identitas yang dibuat untuk membedakan warga asli dan pendatang.

"Ada pemikiran disana, pendatang itu muslim, meskipun sudah 30 tahun tinggal tetap disebut pendatang," kata Zainal.

Zainal juga menyayangkan tindakan represif yang dilakukan aparat keamanan yang terjadi di Papua. Menurutnya, banyak konflik yang terjadi di daerah lain. Namun, khusus untuk di papua terlalu sering tindakan represif yang dilakukan.

Di Papua, setiap ada konflik pasti cepat menyebar dan represif. Sering di Papua setiap ada konflik langsung ditembak entah itu peluru kosong atau peluru isi," ujarnya.

Dirinya mengatakan tindakan petugas keamanan bisa menjadi salah satu faktor masalah ketika terjadi konflik di Papua.

Zainal berharap perdamaian di Tolikara bisa terjadi secepatnya. Dirinya mengatakan perdamaian bisa ditempuh melalui hukum adat. Untuk itu, Zainal ingin agar pemerintah mendukung hal tersebut. Zainal juga menjelaskan pemerintah perlu mengedepankan pendekatan dialog kepada semua pihak yang terlibat.

"Untuk penyelesaian secara adat itu sifatnya lokal, caranya berbeda tiap wilayah sehingga masyarakat setempat harus mencari sendiri proses penyelesaiannya dan pemerintah harus mendukung jika memang ada penyelesaian secara adat," kata Zainal.

Dirinya juga mengutip ucapan Pater Neles Tebay, seorang pemimpin Katolik yang dikenal juga sebagai Koordinator Jaringan Damai Papua. Dalam pernyataannya mengenai insiden di Tolikara, Pater Neles mengungkapkan, "Budaya Papua tidak mengajarkan orang untuk mengganggu, apalagi membakar tempat ibadah.” Menurut Peter, pembakaran mushala di Tolikara adalah peristiwa pertama dalam sejarah Papua di mana sebuah tempat ibadah dibakar.

Diberitakan sebelumnya, terjadi serangan terhadap jemaah yang hendak melaksanakan salat Idul Fitri, Jumat (17/7). Penyerangan membuat jemaah Salat Id bubar. Penyerang lantas membakar beberapa bangunan rumah, kios dan rumah ibadah.

Dalam upaya pengamanan, petugas menembak tiga orang pelaku penyerangan yang tidak mengindahkan peringatan petugas. Sejumlah saksi telah diperiksa terkait kebakaran dan penembakan. (pit/pit)

\section{Hakekat Konflik dalam Masyarakat}


Konflik pada hakekatnya merupakan keniscayaan bagi manusia yang memiliki struktur tubuh yang terdiri dari akal, roh dan raga, yang masing-masing memiliki tuntutan serta keinginan yang beraneka ragam. Keinginan manusia tidak terbatas (to have), manusia menuntut dibebaskan dari berbagai penyakit, malapetaka, dan kekuatan alam agar ia dapat hidup. Mereka pun menuntut kehormatan-kehormatan lain bagi kehidupan, yang pada akhirnya menghadapkan mereka pada realitas yang sangat pelik dan kompleks. Satu sisi, di hadapannya telah hadir keburukan-keburukan yang sudah menjadi hakekat alam, namun di sisi lain juga ada kebaikankebaikan yang bakal menghadapi keburukan itu, sehingga mereka dapat bertahan hidup sekaligus menguasainya.

Manusia memang pada dasarnya memiliki kecenderungan berkonflik antara satu dengan yang lainnya, dan selalu berusaha pula untuk menyelesaikan konflik-konflik tersebut. Karena hakekat tersebut manusia selalu dihadapkan dengan banyak konflik, terlebih konflik yang terjadi di masyarakat, baik konflik vertikal maupun konflik horizontal.

Dalam kehidupan berbangsa dan bernegara di Indonesia, masyarakat Indonesia terbagi atas lapisan-lapisan kelas sosial yang terbentuk dengan sendirinya dan sudah seharusnya ada dalam struktur sosial masyarakat. Indonesia merupakan negara dengan masyarakat yang majemuk, sehingga memunculkan keanekaragaman dalam berbagai aspek yang juga menyebabkan adanya lapisan sosial yang beragam. Struktur masyarakat Indonesia ditandai dengan dua cirinya yang bersifat unik. Dua jenis pelapisan masyarakat Indonesia ialah pelapisan secara horizontal dan pelapisan secara vertikal. Pelapisan horizontal di indikasikan dengan adanya perbedaan ras, agama, serta adat istiadat yang terdapat dalam masyarakat Indonesia. Sedangkan pelapisan vertikal di indikasikan dengan adanya lapisan atas dan lapisan bawah yang didasarkan atas tingkatan ekonomi dan tingkatan-tingkatan lain seperti pekerjaan, pendidikan, dan sebagainya. Pelapisan secara vertikal dalam masyarakat Indonesia dinilai cukup mengkhawatirkan dengan adanya kesenjangan yang begitu kentara antara lapisan atas dan lapisan bawah. Keadaan ini pula yang menjadikan Indonesia selalu dihadapkan pada potensi konflik dalam masyarakatnya. Konflik yang dapat terjadi dalam dua macam, yaitu konflik yang bersifat ideologis, dan konflik yang bersifat politis.

Dalam konflik ideologis, konflik tersebut muncul dalam perbedaan presepsi dari berbagai golongan masyarakat dalam menyikapi suatu hal. Sementara di tingkatan politis, konflik terjadi disebabkan karena adanya pertentangan dalam pembagian sumber kekuasaan. Walaupun 
demikian, tidak menutup kemungkinan konflik yang terdapat dalam masyarakat Indonesia yang majemuk dapat diminimalisir dengan menyelesaikan konflik secara konstruktif (resolusi konflik).

Menurut Killman dan Thomas (1978) dalam Susan (2010), konflik merupakan kondisi terjadinya ketidakcocokan antar nilai atau tujuan-tujuan yang ingin dicapai, baik yang ada dalam diri individu maupun dalam hubungannya dengan orang lain. Kondisi yang telah dikemukakan tersebut dapat mengganggu bahkan menghambat tercapainya emosi atau stres yang mempengaruhi efisiensi dan produktivitas kerja.

Konflik adalah suatu proses antara dua orang atau lebih dimana salah satu pihak berusaha menyingkirkan pihak lain dengan cara menghancurkannya atau membuatnya menjadi tidak berdaya. Konflik itu sendiri merupakan situasi yang wajar dalam setiap masyarakat maupun yang tidak pernah mengalami konflik antar anggota atau antar kelompok masyarakat lainnya, konflik itu akan hilang bersamaan dengan hilangnya masyarakat itu sendiri. Konflik yang dapat terkontrol akan menghasilkan integrasi yang baik, namun sebaliknya, integrasi yang tidak sempurna dapat menciptakan suatu konflik.

Menurut Wood, Walace, Zeffane, Schermerhorn, Hunt, dan Osborn dalam Susan (2010), yang dimaksud dengan konflik adalah:

"Conflict is a situation which two or more people disagree over issues of organisational substance and/or experience some emotional antagonism with one another" yang memiliki arti bahwa konflik adalah suatu situasi dimana dua atau banyak orang saling tidak setuju terhadap suatu permasalahan yang menyangkut kepentingan organisasi dan/atau dengan timbulnya perasaan permusuhan satu dengan yang lainnya.

Menurut Stoner, konflik adalah mencakup ketidaksepakatan soal alokasi sumber daya yang langka atau peselisihan soal tujuan, status, nilai, persepsi, atau kepribadian. Konflik menurut Robbins (1996) dalam Sumaryanto (2010) adalah suatu proses interaksi yang terjadi akibat adanya ketidaksesuaian antara dua pendapat (sudut pandang) yang berpengaruh terhadap pihak-pihak yang terlibat baik pengaruh positif maupun pengaruh negatif. Robbin membagi pandangan ini menjadi 3 bagian, yaitu (1) Pandangan Tradisional, pandangan ini menyatakan bahwa konflik itu hal yang buruk, sesuatu yang negatif, merugikan, dan harus dihindari. Konflik ini suatu hasil disfungsional akibat komunikasi yang buruk, kurang kepercayaan, keterbukaan diantara orang-orang dan kegagalan manajer untuk tanggap terhadap kebutuhan dan aspirasi para karyawan tersebut. (2) Pandangan Kepada Hubungan Manusia, pandangan ini menyatakan 
bahwa konflik dianggap sebagai suatu peristiwa yang wajar terjadi didalam suatu kelompok atau organisasi. Konflik dianggap sebagai sesuatu yang tidak dapat dihindari karena didalam kelompok atau organisasi pasti terjadi perbedaan pandangan atau pendapat. Oleh karena itu, konflik harus dijadikan sebagai suatu hal yang bermanfaat guna mendorong peningkatan kinerja organisasi tersebut. (3) Pandangan Interaksionis, pandangan ini menyatakan bahwa mendorong suatu kelompok atau organisasi terjadinya suatu konflik. Hal ini disebabkan suatu organisasi yang kooperatif, tenang, damai, dan serasi cenderung menjadi statis, apatis, tidak aspiratif dan tidak inovatif. Oleh karena itu, konflik perlu dipertahankan pada tingkat minimum secara berkelanjutan sehingga tiap anggota di dalam kelompok tersebut tetap semangat dan kreatif.

Louis R. Pondy dalam Kenan Spaho (2013) merumuskan lima episode konflik yang disebut "Pondys Model of Organizational Conflict". 2 Menurutnya, konflik berkembang melalui lima fase secara berurutan, yaitu: Laten Conflict, Perceived Conflict, Felt Conflict, Manifest Conflict, dan Conflict Aftermath.

Tahap I; Konflik yang Terpendam (Laten). Konflik ini merupakan bibit konflik yang bisa terjadi dalam interaksi individual ataupun kelompok dalam organisasi, oleh karena set up organisasi dan perbedaan konsepsi, namun masih dibawah permukaan. Konflik ini berpotensi untuk sewaktu-waktu muncul kepermukaan. Konflik laten bersifat mengejutkan, karena datang tiba-tiba dan biasanya sangat berdampak. Konflik laten ini berlaku seperti api di dalam sekam, tak tampak adanya di permukaan, tetapi sangat bermasalah secara tersembunyi di dalam. Gejalanya sulit di deteksi karena bersifat tertutup, justru konflik laten sangat berbahaya. Sama halnya sebuah kekuatan yang disimpan, tentu akan menjadi semakin kuat dan berdaya tinggi bila sewaktu-waktu meledak. Bahaya laten yang tidak terdeteksi dan bisa ditengarai akan menjadi konflik laten yang merusak. Dalam masyarakat yang tertindas misalnya, ketertundukan yang bukan karena kepatuhan dapat menjadi bahaya laten yang terbalik menyerang pada waktunya. Bentuk-bentuk dasar dari situasi ini seperti : Saling ketergantungan kerja, perbedaan tujuan dan prioritas, faktor birokrasi, perbedaan status, dan sumber daya yang terbatas.

Tahap II; Konflik yang Terpersepsi. Fase ini dimulai ketika para aktor yang terlibat mulai mengkonsepsi situasi-situasi konflik termasuk cara mereka memandang, menentukan pentingnya isu-isu, membuat asumsi-asumsi terhadap motif-motif dan posisi kelompok lawan.

${ }^{2}$ Spaho, Kenan, Organizational, Communication and Conflict Management, Management, Vol. 18, 2013, 1, pp. 103118 Professional paper dalam https://www.efst.hr/management/Vol18No1-2013/6-Spaho.pdf. 
Tahap III; Konflik yang Terasa. Fase ini dimulai ketika para individu atau kelompok yang terlibat menyadari konflik dan merasakan pengalaman-pengalaman yang bersifat emosi, seperti kemarahan, frustrasi, ketakutan, dan kegelisahan yang melukai perasaan.

Tahap IV; Konflik yang Termanifestasi. Pada fase ini salah satu pihak memutuskan bereaksi menghadapi kelompok dan sama-sama mencoba saling menyakiti dan menggagalkan tujuan lawan. Misalnya agresi terbuka, demonstrasi, sabotase, pemecatan, pemogokan dan sebagainya.

Tahap V; Konflik Sesudah Penyelesaian. Fase ini adalah fase sesudah konflik diolah. Bila konflik dapat diselesaikan dengan baik hasilnya berpengaruh baik pada organisasi (fungsional) atau sebaliknya (disfungsional).

Mengkaji dari hakekat konflik di atas, memperkuat dan memperjelaskan sesungguhnya sangat diperlukan untuk memahami resolusi konflik bagi setiap pribadi maupun kelompok masyarakat Indonesia terutama dalam pendekatan komunikasi.

\section{Resolusi Konflik dalam Perspektif Komunikasi}

Konsekuensi makhluk sosial senantiasa menginginkan adanya hubungan dengan manusia lainnya, menjadikan manusia selalu ingin mengetahui lingkungan sekitarnya, bahkan ingin mengetahui apa yang terjadi dalam dirinya, rasa ingin tahu ini memaksa manusia untuk melakukan komunikasi dengan sesamanya. Dalam hidup bermasyarakat atau berorganisasi, karena dua modus eksistensi manusia akan menimbulkan suatu konflik pada diri seseorang maupun dengan orang lain. Diperlukan suatu komunikasi yang merupakan sebuah kebutuhan bagi setiap manusia untuk menyampaikan informasi maupun keinginan dan ketidak inginan baik verbal maupun non verbal. Masyarakat tanpa adanya komunikasi maka tidak akan terbentuk masyarakat atau organisasi kemasyarakatan. Konflik yang terjadi pada diri seseorang di akibatkan adanya komunikasi yang tidak lancar antara seorang informan dan penerima informasi baik secara langsung maupun tidak langsung, dan konflik yang terjadi dapat menimbulkan adanya perpecahan maupun permusuhan di antara orang tersebut dengan orang lain baik secara individu maupun di dalam suatu masyarakat. Konflik ini adalah suatu realitas unik yang merupakan bagian yang tidak terpisahkan, yang disadari maupun tidak kita sadari akan senantiasa mengiringi semua aspek kehidupan manusia. Tidak ada seorangpun selama ia hidup yang dapat menghindar dari konflik, namun setiap orang memiliki cara yang berbeda dalam 
menghadapi, menyikapi dan menyelesaikan konflik. Konflik akan terus ada selama roda kehidupan ini berjalan.

Dalam kehidupannya, manusia memerlukan komunikasi, baik berkomunikasi dengan individu lain maupun dengan kelompok atau masyarakat. Hal ini menunjukkan bahwa manusia terbentuk dari hasil integrasi sosial dengan sesama dalam suatu kelompok atau masyarakat. Muhammad (2005) menyatakan bahwa pentingnya komunikasi bagi manusia tidaklah dapat dipungkiri, begitu pula halnya bagi suatu organisasi. Dengan adanya komunikasi yang baik, suatu organisasi dapat berjalan lancar dan berhasil. Sebaliknya tidak adanya komunikasi akan menimbulkan konflik antara anggota organisasi dan dampaknya mengganggu komunikasi dalam organisasi tersebut.

Brent D. Ruben (dalam Muhammad 2005) menyatakan definisi komunikasi adalah suatu proses melalui mana individu dalam hubungannya, dalam kelompok, dalam organisasi dan dalam masyarakat menciptakan, mengirimkan, dan menggunakan informasi untuk mengkoordinasikan lingkungannya dan orang lain.

Muncul pertanyaan, dalam kondisi apa komunikasi mengurangi konflik? Mereka memeriksa empat model komunikasi. Dari model ini mereka mendapatkan tujuh prinsip bagaimana komunikasi dapat mengurangi konflik.

Model encoding-decoding memandang komunikasi manusia sebagai masalah pengkodean informasi (misalnya, merumuskan kalimat), transmisi pesan (misalnya, berbicara), dan decoding pesan (misalnya, mendengarkan dan pemahaman). Komunikasi yang sukses membutuhkan saluran yang jelas transmisi, dan kode bersama. Kesalahpahaman hasil dari pesan salah menerjemahkan, atau dari celah atau suara asing dalam pesan. Dari model ini mereka memperoleh prinsip pertama : "Hindari saluran komunikasi dengan rasio signal-to-noise yang rendah, jika itu tidak mungkin meningkatkan redundansi dengan menegaskan kembali ide yang sama dalam berbagai bentuk. ${ }^{3}$

Pada model ini disampaikan bahwa komunikasi digambarkan sebagai transfer informasi melalui kode, dan kode ini adalah sistem yang memetakan satu set sinyal ke satu set makna. Dalam paradigma pertama (encoding-decoding) pula hal yang menjadi bahasan penting terkait

${ }^{3}$ Deutsch, Morton and Coleman, Peter T, The Handbook of Conflict Resolution Theory and Practice. (San Francisco: Jossey-Bass, Publishers, 2000), h.133 
komunikasi efektif jika pesan-pesan mempunyai arti atau makna yang sama antara si penerima dan pemberi pesan.

Model intensionalis mengakui bahwa kata-kata yang sama dapat memiliki arti yang berbeda. Pada model komunikasi ini melibatkan, mengakui niat komunikatif masing-masing. Komunikasi yang efektif membutuhkan latar belakang pengetahuan bersama, terutama bahasa yang sama dan budaya bersama. Missed-communication hasil dari kurangnya latar belakang umum. Missed-communication yang terjadi selama konflik sebagai kata-kata pembicara ditafsirkan sesuai dengan pendengar mereka terbentuk sebelumnya pengertian tentang niat mereka. Prinsip kedua ini mengarahkan pendengar untuk mencoba memahami makna pembicara yang dimaksud.

Model ketiga, Perspektif-Taking mengarahkan speaker ketika memutuskan apa yang harus dikatakan, untuk mempertimbangkan apa yang pendengar mereka akan membawa mereka berarti. Paradigma ketiga ini mengakui bahwa individu dengan bahasa dan budaya yang sama memiliki perspektif yang berbeda pada dunia. Model ini mengarahkan speakeru ntuk merancang pesan mereka agar sesuai perspektif penonton mereka. Missed-communication dapat terjadi ketika pembicara mengasumsikan lebih kesamaan dalam perspektif dengan pendengar daripada benar-benar ada, atau ketika pemahaman pembicara dari perspektif pendengar berbasis prasangka dan stereotipe yang tidak akurat. Kesulitan lain muncul ketika pembicara secara bersamaan menangani audiens yang berbeda. Meskipun masalah ini, prinsip keempat penulis mengarahkan speaker untuk mengambil perspektif pendengar, mereka memperhitungkan dalam merumuskan pesan mereka.

Model ke empat adalah Model dialogis, memandang komunikasi sebagai kooperatif (cooperative), proses kolaboratif. Makna muncul dari situasi komunikatif, dan hanya dapat dipahami dalam konteks itu. Model ini tidak seperti yang lain, memperlakukan pendengar sebagai peserta aktif dalam penciptaan pemahaman bersama. "Pendengar aktif mengajukan pertanyaan, mengklarifikasi pernyataan ambigu, dan bersusah payah untuk memastikan bahwa mereka dan rekan mereka memiliki pemahaman yang sama tentang apa yang telah dikatakan. ${ }^{4}$

Spiegel (1994) menjelaskan ada lima tindakan yang dapat kita lakukan dalam resolusi konflik. 
Pertama; berkompetisi. Tindakan ini dilakukan jika kita mencoba memaksakan kepentingan sendiri di atas kepentingan pihak lain. Pilihan tindakan ini bisa sukses dilakukan jika situasi saat itu membutuhkan keputusan yang cepat, kepentingan salah satu pihak lebih utama dan pilihan kita sangat vital. Hanya perlu diperhatikan situasi menang - kalah (win-win solution) akan terjadi disini. Pihak yang kalah akan merasa dirugikan dan dapat menjadi konflik yang berkepanjangan. Tindakan ini bisa dilakukan dalam hubungan atasan-bawahan, dimana atasan menempatkan kepentingannya (kepentingan organisasi) di atas kepentingan bawahan.

Kedua; menghindari konflik. Tindakan ini dilakukan jika salah satu pihak menghindar dari situasi tersebut secara fisik ataupun psikologis. Sifat tindakan ini hanyalah menunda konflik yang terjadi. Situasi menang kalah terjadi lagi disini. Menghindari konflik bisa dilakukan jika masing-masing pihak mencoba untuk mendinginkan suasana, membekukan konflik untuk sementara. Dampak kurang baik bisa terjadi jika pada saat yang kurang tepat konflik meletus kembali, ditambah lagi jika salah satu pihak menjadi stres karena merasa masih memiliki hutang menyelesaikan persoalan tersebut.

Ketiga; Akomodasi, yaitu jika kita mengalah dan mengorbankan beberapa kepentingan sendiri agar pihak lain mendapat keuntungan dari situasi konflik itu. Disebut juga sebagai self sacrifying behaviour. Hal ini dilakukan jika kita merasa bahwa kepentingan pihak lain lebih utama atau kita ingin tetap menjaga hubungan baik dengan pihak tersebut. Pertimbangan antara kepentingan pribadi dan hubungan baik menjadi hal yang utama di sini.

Keempat; Kompromi atau Negosiasi. Tindakan ini dapat dilakukan jika kedua belah pihak merasa bahwa kedua hal tersebut sama-sama penting dan hubungan baik menjadi yang utama. Masing-masing pihak akan mengorbankan sebagian kepentingannya untuk mendapatkan situasi menang-menang (win-win solution).

Kelima; Berkolaborasi atau Bekerjasama. Menciptakan situasi menang-menang dengan saling bekerjasama (win-win solution). Pemecahan sama-sama menang dimana individu yang terlibat mempunyai tujuan kerja yang sama. Perlu adanya satu komitmen dari semua pihak yang terlibat untuk saling mendukung dan saling memperhatikan satu sama lainnya.

\section{Analisa Kritis dan Catatan Kecil: Konflik Horizontal Pola Konflik "Baru" di Indonesia?}

Beragamnya etnis, agama dan sosial yang hidup di Indonesia menjadikan Indonesia sebagai negara dengan masyarakat multikultural terbesar di dunia. Usman Pelly (2003) 
menyatakan masyarakat multikultural adalah masyarakat negara, bangsa, daerah, bahkan lokasi geografis terbatas seperti kota atau sekolah yang terdiri atas orang-orang yang memiliki kebudayaan yang berbeda-beda dalam kesederajatan. Pada hakikat-nya masyarakat multikultural adalah masyarakat yang terdiri atas berbagai macam suku yang masing-masing mempunyai struktur budaya (culture) yang berbeda-beda. Dalam hal ini masyarakat multikultural tidak bersifat homogen, namun memiliki karakteristik heterogen di mana pola hubungan sosial antarindividu di masyarakat bersifat toleran dan harus menerima kenyataan untuk hidup berdampingan secara damai (peace co-exixtence) satu sama lain dengan perbedaan yang melekat pada tiap entitas sosial dan politiknya (Gunawan, 2011; 216).

Kondisi masyarakat multikultural ini cenderung rawan konflik, khususnya konflik horizontal (komunal). Konflik horizontal atau konflik antar-entis, suku, kelompok, dan agama di Indonesia sudah ada sejak lama di Indonesia. Bahkan sejak Indonesia masih berbentuk kerajaankerajaan, perang antar kerajaan dan perebutan kekuasaan antar-saudara selalu terjadi. Namun, pola konflik ini dapat ditangani dengan berkumpulnya para pemuda Indonesia pada tahun 1928 dan melahirkan Sumpah Pemuda, dimana janji para pemuda Indonesia dan seluruh rakyat Indonesia untuk berbangsa, bernegara, dan berbahasa satu yaitu Indonesia.

Doktrin kebangsaan seperti Bhinneka Tunggal Ika, "berbeda-beda tapi tetap satu juga" dilakukan oleh pemerintah mengingat keberagaman etnis di Indonesia. Negara Indonesia yang luas dan besar akan sangat sulit dikelola tanpa adanya kesatuan paham kebangsaan guna mendukung gerak pembangunan negara ke arah yang lebih baik.

Kondisi sosial dan perekonomian masyarakat ditata dengan baik guna mencapai kesejahteraan. Pemerintahan Indonesia di bawah kendali Orde Lama masih belum kuat dengan banyaknya intrik dan politisasi oleh para elite negara. Sehingga program-program kesejahteraan masyarakat masih berjalan terseok-seok. Masih adanya perang ideologi antara blok barat (Amerika) dan blok timur (Uni Soviet) saat itu menjadikan Indonesia harus banyak fokus pada politik luar negeri. Sebagai negara-bangsa baru, Indonesia memerlukan dukungan dan relasi yang baik dengan negara-negara tetangga. Hal ini guna memantapkan posisi Indonesia sebagai negara-bangsa berdaulat di mata dunia.

Program transmigrasi pemerintah turut pula menyumbang sumbu konflik di masyarakat. Dengan dalil pemerataan ekonomi dan penduduk, pemerintah melakukan penyebaran penduduk (mayoritas etnis Jawa) ke beberapa daerah terpencil tapi memiliki sumber daya alam yang 
melimpah. Pola perpindahan penduduk ini menjadi kemajemukan yang kompleks bagi masyarakat. Kompleksitas itu dapat dilihat melalui realitas bahwa penduduk pendatang cenderung mengalami peningkatan ekonomi lebih tinggi dari pada pribumi. Ketimpangan ekonomi ini menyebabkan kecemburuan sosial yang selama Orde Baru hanya berada dalam tataran "bawah tanah" saja.

Bukan hanya ketimpangan ekonomi yang begitu tinggi, kegagalan akulturasi pendatang dengan pribumi juga menjadi faktor munculnya benih konflik. Kaum pendatang cenderung eksklusif dan tidak mau membaurkan dirinya dengan masyarakat setempat. Kondisi ini diperparah oleh stereotip-stereotip yang berkembang baik di masyarakat pendatang maupun pribumi.

Konflik horizontal di Indonesia pun banyak disebabkan oleh komunikasi. Temuan dari hasil penelitian Maria Lamria (2004), Yohanes Bahari (2005), dan Ira Mirawati (2011) mengindikasikan bahwa konflik sosial, etnis, ras, dan agama antar warga (horizontal) disebabkan oleh kegagalan dalam mengelola pesan-pesan verbal dan non-verbal. Masyarakat pendatang cenderung menggunakan bahasa yang berbeda dengan penduduk lokal meskipun telah ada kesepakatan (tidak tertulis) untuk menggunakan bahasa Indonesia sebagai bahasa pemersatu bangsa, akan tetapi logat atau aksen yang digunakan oleh masing-masing orang yang berinteraksi masih mengikuti logat atau aksen dari sukunya masing-masing. Kondisi ini menyebabkan sulitnya menerima pesan yang disampaikan, lalu terjadi kesalahan interpretasi, hingga akhirnya memicu konflik.

Kegagalan pengelolaan pesan tidak hanya terjadi secara verbal (lisan), pesan non-verbal juga ikut menyumbang terjadinya konflik antar warga. Mirawati (2011) mengatakan bahwa konflik antara Suku Dayak dan Madura di Kalimantan Barat juga disebabkan karena gaya berpakaian dan bersosialisasi masyarakat Suku Madura yang sering membawa Clurit (senjata khas Madura) dan parang kemanapun mereka pergi. Hal ini mengindikasikan bahwa mereka (Suku Madura) merasa dirinya hebat dan jagoan. Faktor Emosional pun tidak bisa dilepaskan dari Suku Madura. Mereka cenderung akan ringan tangan (membunuh dengan parang atau Clurit) orang yang bersengketa dengan mereka, termasuk jika mereka bersengketa dengan orang dari Suku Dayak.

Selama konflik Ambon dari tahun 1999 hingga 2002 yang mengakibatkan korban jiwa hampir 10 ribu jiwa, ternyata juga menyeret peran media massa dalam pusaran konflik (Cangara, 
2005; 8-10). Dalam suasana perang (konflik) media dapat dibagi secara tegas dalam dua kategori, yaitu, hot media (media "panas") dan cold media (media "dingin"). Media "panas" terindikasi sebagai media yang cenderung memanaskan suasana, selalu mencari titik-titik kerusuhan atau konflik untuk selanjutnya disiarkan dengan cara yang bombastis. Media jenis ini cenderung mengabaikan etika dalam setiap liputannya. Tujuan dari media seperti ini adalah mencari jumlah oplah atau rating yang tinggi. Media jenis ini yang menjadikan konflik tetap bertahan dan menjadi sulit dikendalikan.

Sedangkan media "dingin" terindikasi sebagai media yang cenderung menjalankan teknik-teknik peace journalism (jurnalisme damai). Paradigma ini dilandaskan bahwa perang atau konflik hanya membawa kepada ke sengsaraan bagi masyarakat dan kehancuran bagi peradaban manusia. Dalam setiap liputannya, media "dingin" cenderung mengabarkan sisi kemanusiaan yang terenggut oleh konflik dan berupaya agar semua masyarakat -yang berkonflik -sadar akan dampak buruk yang ditimbulkan konflik. Media jenis ini juga berupaya terciptanya resolusi konflik secara tepat dan bermartabat bagi seluruh masyarakat.

\section{Kesimpulan}

Konflik horizontal dapat dimaknai sebagai konflik yang melibatkan gesekan dan pertempuran antar masyarakat. Konflik yang terjadi di berbagai daerah di Indonesia menunjukkan antara lain kurangnya kemampuan pemerintah dalam mengatasi penyebab terjadinya konflik. Konflik muncul dengan menggunakan simbol-simbol etnis, agama, dan ras. Hal ini terjadi akibat adanya akumulasi "tekanan" secara mental, spiritual, politik sosial, budaya dan ekonomi yang dirasakan oleh sebagian masyarakat. (Lamria, 2004).

Banyak ilmuwan dan peneliti sosial merinci dan memformulasikan penyebab-penyebab konflik horizontal di Indonesia. Meskipun kebanyakan adalah faktor ketimpangan ekonomi dan kegagalan akulturasi masyarakat pendatang dengan masyarakat pribumi. Namun yang paling penting dan tidak bisa dilupakan begitu saja adalah faktor komunikasi.

Komunikasi selalu menjadi masalah yang melekat pada konflik antar etnis. Kalau bukan sebagai penyebab terjadinya konflik, maka ia menjadi masalah yang kemudian muncul pascakonflik. Sayangnya, urgensi komunikasi dalam kehidupan tidak dilihat sebagai aspek penting yang perlu dibenahi maka yang kemudian terjadi adalah konflik horizontal yang tak kunjung habis dan cenderung akan berulang, mengingat negara Indonesia adalah negara multi-etnis 
terbesar di dunia. Komunikasi sebagai pemicu terjadinya konflik dikarenakan kemacetan komunikasi yang terjadi baik antara elite politik (pemerintah) dengan masyarakat ataupun sesama masyarakat. Komunikasi dapat menjadi trigger (pemicu) terjadinya konflik baik vertikal maupun horizontal. Namun komunikasi juga dapat menjadi pencegah terjadinya konflik. Komunikasi dapat pula menjadi sarana sebagai jalan keluar dari sebuah konflik. 
Daftar pustaka

Deutsch, Morton and Coleman, Peter T. (2000). The Handbook of Conflict Resolution Theory and Practice. Jossey-Bass, Publishers: San Francisco.

Fromm, Erich. 2008, originally published in 1976. To Have or To Be?. New York: Continuum.

Ig. Wursanto. 2005. Dasar-dasar Ilmu Organisasi. Yogyakarta: Penerbit Andi. Jakarta: PT. Raja Grafindo Persada.

Maftuh, Bunyamin. (2005). Pendidikan Resolusi Konflik. Program Studi Pkn Sekolah Pascasarjana UPI; Bandung.

Nasikun. 1995. “ Struktur Majemuk Masyarakat Indonesia dalam Masalah Integrasi

Nasikun. 1995. “Struktur Majemuk Masyarakat Indonesia”, dalam Sistem Sosial Indonesia.

Nasional”, dalam Sistem Sosial Indonesia. Jakarta: PT. Raja Grafindo Persada.

Pruitt, Dean G. \& Jeffrey Z. Rubin. (2009). Teori Konflik Sosial. Pustaka Pelajar; Yogyakarta.

Spaho, Kenan, Organizational, Communication and Conflict Management, Management, Vol. 18, 2013, 1, pp. 103-118 Professional paper dalam https://www.efst.hr/management/Vol18No1-2013/6-Spaho.pdf.

Sumaryanto. 2010. Manajemen Konflik Sebagai Salah Satu Solusi Dalam Pemecahan Masalah. Yogyakarta: UNY. dalam http://staff.uny.ac.id/sites/default/files/pengabdian/drsumaryanto-mkes/6-manajemen-konflik-sebagai-salah-satu-solusi-dalam-pemecahanmasalah.pdf.

Susan, Novri. (2010). Pengantar Sosiologi Konflik dan Isu-isu Konflik Kontemporer. Kencana Prenada Media Group; Jakarta.

Susan, Novri. 2010. Pengantar Sosiologi Konflik dan Isu-isu Konflik Kontemporer. Jakarta; Kencana Prenada Media Group.

Wirawan. (2009). Konflik Dan Manajemen Konflik:Teori, Aplikasi, dan Penelitian. Salemba Humanika;Jakarta. 
